\title{
EFFECT OF IMPLEMENTATION OF HUMAN RESOURCES PRACTICES TO EMPLOYEES PERFORMANCE OF LOGISTIC COMPANIES IN BATAM
}

\author{
Yuswardi \\ ${ }^{1}$ Manajemen, Universitas Internasional Batam, Kota Batam \\ email: yandi.suprapto@uib.ac.id
}

\begin{abstract}
The aims of this paper is to explore the effect of recruitment and selection, compensation, training and performance appraisal on employee performance for employees in the context of logistics companies in Batam. In this study, at the first phase, a structured questionnaire was developed by using Likert 5 scale and applied on 300 respondents, who are currently working at different positions of logistics companies in Batam. The study revealed that all the factors significantly create impact on the employees' performance. This study can significantly contribute to the recruiters of human resources of different logistics companies, as it clearly demonstrates how positive contribution can be derived from the employees using appropriate strategies.
\end{abstract}

Keywords: logistics company, recruitment and selection, training, compensation, performance appraisal, employee performance

\section{PRELIMINARY}

The express shipping or courier business over the next year is predicted to grow by $15 \%$, supported by the growing development of online shopping. Many people now shift their shopping choices to shopping online, besides being easier sometimes the seller also provides a special price that is cheaper than shopping at the store. This is due to the lower cost of production and distribution compared to the cost of selling directly at the store. More convenience is offered by market places in Indonesia.

Association of Indonesian Express, Post and Logistics Shipping Services (Asperindo), the growth of this courier service will increase in the future with increasing public interest in online shopping. This is certainly increasingly encouraging the development of freight forwarding and logistics companies. And to develop a more advanced logistics company, employees are needed who are able to work well and fully dedicated to the progress of the company. At present, with sales contributing to total retail sales of only $1 \%$, the e-commerce business has contributed $3 \%$ of the total supply of 8.1 million $\mathrm{m} 2$ of logistics warehouses. With growth of $20 \%$ per year, the contribution of e-commerce is expected to reach $7 \%$ $8 \%$ or valued at USD14.47 billion in 2021 or an increase of 2.08 times. This means doubling the logistical space needed. In general, the logistics industry will grow thanks to the performance of the consumption sector, in line with Indonesia's population growth which is expected to reach 270 million in 2020. Compared to 2010, the level of consumption expenditure increased 1.42 times to Rp1.309 trillion.

The performance of e-commerce in Indonesia is growing rapidly because the industry has penetrated all segments, not limited to large companies. The presence of logistics support companies has greatly helped the development of e- 
commerce that provides logistical handling services for e-commerce businesses, ranging from warehousing, distribution, to product photos. The presence of this company makes ecommerce companies can focus on sales without having to bother handling shipping goods. At present there are dozens of logistics companies such as Wahana Logistik, Pandu Logistik, Republic Express (RPX), Cahaya Logistik, Synergy First Logistics, PT Pos Indonesia, and Citra Van Titipan Kilat (TIKI) and PT Tiki Lintas Nugraha Ekakurir (JNE). The increasing number of logistics companies also makes the small and medium business sector (SMEs), including in the field of goods sales grow rapidly.

Based on the problems above, the objectives of this study are:

a. To find out the relationship between recruitment and selection on employee performance

b. To find out the relationship between compensation and employee performance

c. To find out the relationship between job training and employee performance

d. To find out the relationship between performance appraisal and employee performance

\section{THEORETICAL FRAMEWORK AND HYPOTHESIS FORMULATION}

\section{Prior Research}

Hassan (2016) examined and analyzed the effect of the application of human resource practices on the performance of the company's employees. This research was conducted by distributing questionnaires to employees of companies in the field of convection in Pakistan to obtain research data. Some independent variables tested were regarding compensation, career planning, performance appraisal from employees, work training programs and employee involvement, then tested on employee performance variables. Convection companies are labor-intensive industries.

Bida et al., (2017) examined the influence and relationship between employee selection and recruitment variables, training \& development, compensation, performance appraisal and succession plans on employee performance in a company in Malaysia as an object in this study. This research was conducted as input for companies related to employee performance. Company performance depends on human resources because it has the skills, knowledge, and competencies needed for implementing organizational strategy and planning.

Jouda et al., (2016) in this study examines the impact of human resource management practices (HRM) on employee performance at the Islamic University of Gaza (IUG) in Palestine. Primary data was collected through a questionnaire from 115 employees from IUG. The contribution of this research is three. First, to investigate the relationship between HRM practices and employee performance. Second, this study provides meaningful insights about HRM practices and employee performance in higher education institutions in Palestine. Third, from a practical perspective, this study draws attention to the fact that there is a need to develop HRM practices that can increase the effectiveness and sustainability of higher education institutions in Palestine.

The purpose of this research from Siddiqi and Tangem (2018) is to explore the influence of the work environment, compensation and motivation that influence and can improve performance in employees in the insurance industry in Bangladesh. In this study, a structured questionnaire was developed using a Likert 5 scale and distributed to 150 respondents, who worked in insurance companies in Bangladesh. The results of this study revealed that all factors 
significantly had an impact on employee performance. This study contributes to the recruitment of human resources in companies in the insurance field, because positive contributions can be obtained from employees using the right strategy.

In this study, Kaveri \& Prabakaran (2013) examined the effect of work training variables, motivation, work environment and compensation as an independent variable on employee performance as the dependent variable. This study sets out the effects of job design, training and development, motivation, supervisory support, work environment and compensation for employee work performance in a leather goods logistics company in India. Data were collected using a questionnaire and analyzed using descriptive statistics. Based on the findings, the variables of job design, support and work environment have a positive relationship with employee performance. Meanwhile training and development variables, motivation and compensation are also significantly related to employee performance.

This research by Bowra et al., (2012) aims to examine the relationship and influence of elements of human resource practices, namely compensation, performance evaluation, and employee promotion of employee performance. Survey of 235 banking employees through a questionnaire to investigate the impact of HR practices on employee performance. The test results show that, employees feel the performance and HR practices have a positive and significant relationship.

Asim's research (2013) aims to examine the effect of the variable award, promotion and training as an independent variable on employee performance. The study was conducted on university lecturers and administrative staff in Pakistan. This study explains the impact of motivation levels between employee performance and the mediation of training needed by universities in Pakistan. 118 respondents indicated the impact of HR needs such as promotion, employee motivation, training and its effect on employee performance.

Shabbir's research regarding the relationship and influence of independent variables namely wage practices, performance evaluations and employee promotion policies on the performance of employees of pharmaceutical industry companies in Pakistan. The results of Shabbir's research (2014) show the influence of compensation variables, performance evaluation and employee promotions on improving the performance of employees of pharmaceutical companies in Islamabad, Pakistan.

\section{Definition of Dependent Variable}

According to Tabiu \& Nura (2013), employee performance is the work of employees given to companies or organizations that can be measured by work standards set together. The achievement of the goals of an organization is inseparable from the ability or competence of qualified and committed human resources in efforts to achieve organizational goals.

According to Bida et al., (2017) employee performance is the result of work and work in quality and quantity carried out by employees in carrying out their duties in accordance with the responsibilities given to them compared to the expected achievements of employees. Performance is the implementation of work in carrying out activities that fit the strategy in a variety of technical, tactic and practical activities in accordance with the goals to be achieved together.

\section{Relationship Between Variables}

The Effect of Recruitment and Selection on Employee Performance

According to Tabiu \& Nura (2013), recruitment is a process in producing a group of potential applicants to occupy a 
job position in an organization while selection is the process of using certain instruments that are suitable for selecting the most suitable candidates for the job from a group of applicants in accordance with the objectives organization.

The recruitment and selection process is one of the most important functions of human resources because it is an employee's entry point into an organization. The progress of an organization can be determined when the company is able to recruit suitable candidates and have the ability and commitment to work well for the progress of an organization. Previous studies from Jouda et al., (2016), Tanveer et al., (2011), Bida et al., (2017) and Al Qudah et al. (2014) showed a relationship between recruitment and selection with employee performance.

\section{Effect of Compensation on Employee Performance}

According to Hussain and Rehman (2013), compensation is a gift or something that an employee receives in return for his performance and business to the company in terms of work. Compensation can be given in cash financial forms such as salaries, wages, benefits, bonuses, incentives and others. Rewards that come from outside the employee that are usually given by the company are called extrinsic rewards.

According to Shabbir (2014), the company's operations are always related to compensation which is one of the important things in improving employee performance. Therefore, in improving employee performance, compensation fulfillment is needed to support employee work motivation. It is very important to create a good cooperative relationship between employees and companies as employers. If this relationship is well established it will be easy to achieve the goals of a company. Both parties must understand each other about the interests and needs of all parties. The company's needs will be met through work carried out by employees, and through that work employees get compensation in accordance with their contribution to the company. Non-financial compensation in the form of providing a safe, comfortable and conducive work environment. Whereas financial compensation in the form of salary or wages, incentives, benefits, bonuses. Previous studies from Kaveri \& Prabakaran (2013), Shabbir (2014) and Jouda et al., (2016) showed a significant relationship between compensation and employee performance.

\section{The Effect of Job Training on Employee Performance}

Job training is a company's effort to improve employee work competency through education, teaching, development and work experience provided in a systematic and measurable way (Tanveer et al., 2011). Training can be done inside or outside the work environment depending on the needs and plans of the company. Appropriate employee training is needed to improve performance, competence, work ability and for the sustainable development of the company's human resources. Previous studies from Tanveer et al., (2011), Hussain and Rehman (2013), Bida et al., (2017) and Bercu (2017) showed a significant relationship between training and employee performance.

\section{The Effect of Performance Appraisal on Employee Performance}

According to Jouda et al., (2016), performance appraisal is a process for evaluating employee performance compared to work standards set by the company and then communicating that information to employees for the purpose of improving and improving work performance. Work assessment is also needed by employees in the process of self-introspection toward a position in work. According to Shabbir (2014), performance evaluation or evaluation is a 
compulsory process carried out by the company, where the company evaluates the attitude and or quality of work of employees in a company within a certain period of time. This performance appraisal is an input about the strengths and weaknesses of an employee. Performance appraisal plays an important role in developing the company through the process of increasing employee work efficiency (Shabbir, 2014).

\section{RESEARCH METHODS}

\section{Research design}

According to Sugiyono (2010), based on the level of clarity, this research is a descriptive study, but the type of data used in this study is quantitative. This study uses a survey method approach to obtain data from a group of respondents by means of researchers conducting data collection by distributing questionnaires, tests, and structured interviews. Comparative causal research is a type of conclusive research that aims to obtain empirical evidence about the relationship and influence between the independent variables and the dependent variable, namely recruitment and selection, compensation, training and work assessment of the dependent variable, namely employee performance in logistics companies in Batam .

\section{Object of research}

The population in this study were employees of logistics companies in Batam. The number of research samples is determined using the Krejcie Morgan Table, with a population of around 800 people who are employees of the shipping company, then the minimum required research sample is 260 respondents, but to anticipate the existence of questionnaires that are not returned or are not filled in completely, the number of questionnaires 300 respondents were distributed.

\section{Definition of Variable}

- Recruitment is a process to produce a group of potential applicants to fill job positions in an organization while selection is the process of using certain instruments that are suitable for selecting the right prospective employee from a group of applicants who are qualified for the job (Al Qudah et al., 2014) . The questionnaire was adopted from Tabouli et al., (2016) with a total of 5 statements. Statements are measured using a 5point Likert scale ranging from strongly disagree (1) to strongly agree (5).

- Compensation is the provision of material rewards to employees as a remuneration for work performance to the company (Shabbir, 2014). Questionnaire statements were adopted from Tabouli et al., (2016) with a total of 5 statements. Statements are measured using a 5-point Likert scale ranging from strongly disagree (1) to strongly agree (5).

- Training is a formal and systematic learning process through education, teaching, development and experience planned to improve the skills and competencies of employees (Imran and Tanveer, 2015). Questionnaire statements were adopted from Imran and Tanveer (2015) with a total of 8 statements. Statements are measured using a 5-point Likert scale ranging from strongly disagree (1) to strongly agree (5). The recruitment and selection variable has 5 statements, ranging from strongly disagree (1) to strongly agree (5).

- Performance appraisal is a process of evaluating how well employees perform work compared to specified work standards and then communicating the information to employees. Questionnaire statements were adopted from Tabouli et al., (2016) with a total of 4 statements. 
Statements are measured using a 5point Likert scale ranging from strongly disagree (1) to strongly agree (5). The recruitment and selection variable has 5 statements, ranging from strongly disagree (1) to strongly agree (5).

Employee performance

Tabouli et al., (2016) said that employee performance is a work of quality and quantity achieved by employees in carrying out tasks in accordance with the responsibilities given to them. Questionnaire statements were adopted from Tabouli et al., (2016) with 5 statements. Statements are measured using a 5-point Likert scale, ranging from strongly disagree (1) to strongly agree (5).

\section{Data collection technique}

In carrying out this study, the authors of this study, the authors used primary data collected from questionnaires distributed to respondents who were the object of research. The questionnaire contains general questions to find out the demographics of the respondents as well as questions from each of the variables tested. Secondary data obtained from the results of previous studies, research journals, books related to research and also articles or data obtained from internet site sources.

\section{ANALYSIS AND DISCUSSION Descriptive statistics}

Questionnaires were distributed as many as 300 sheets to employees of logistics and logistics companies in Batam. The number of returned questionnaires was 288 questionnaires and 12 questionnaires that did not return, then the data obtained was processed by the SPSS program. Based on the sex of the respondents, it is known that women are the majority in this study with a total of 148 and male respondents as many as 139. Based on the age of the respondents, it is known that the majority of respondents aged 18-
25 years or classified as young age that is as much as 105 respondents or $36.5 \%$ of total respondents. Based on the education level of respondents, it can be seen that the majority of respondents educated at the vocational / high school level are 194 respondents or $67.4 \%$ of the total respondents. Then the data description continues based on the amount of monthly income. From this data it is known that as many as 133 respondents earn Rp. 3.5-4.5 million per month, 126 respondents earn Rp. 4.6-6 million. monthly and as many as 29 respondents earn more than Rp 6 million per month. Based on the length of work there are 168 respondents who have worked for 13 years, 63 respondents have worked for 4-6 years and as many as 57 respondents have worked for more than 6 years

\section{Quantitative Test Results}

Outlier Test Results

Outlier test is useful to find out whether there are research respondents who provide data deviating from the average. If the $\mathrm{z}$-score is greater than 3.0 or smaller -3.0 then the respondent will be considered deviant and discarded from the next test (Ghozali, 2011). In this study, there were no outlier respondents, so all of them were included in the next test and there were 288 permanent respondents.

\section{Data Quality Test}

Validity Test Results

In the validity test of 25 statements of all recruitment and selection variables, compensation, job training, performance appraisal and employee performance, all are valid, so that all variables are included in the subsequent data processing. This test will be valid if it has a factor load value greater than 0.6 (Ghozali, 2011).

\section{Reliability Test Results}

Based on the results of the reliability test, Cronbach alpha values obtained for all variables show exceeding 
the limit value of 0.6 (Ghozali, 2011) so that all variables are declared reliable.

\section{Classic assumption test Normality Test Results}

The results of the normality test show the data have a normal distribution and spread along a diagonal line, it is concluded that all regression models are feasible to use because they meet the normality assumption.

\section{Multicollinearity Test Results}

The multicollinearity test results on the independent variable showed a tolerance value below 0.10 , which means there is no correlation between the independent variables. The test results show a VIF value of less than 10 and a tolerance value of more than 0.1 . So, it can be concluded that there is no multicollinearity between independent variables in regression (Ghozali, 2011).

\section{Heterokedasticity Test Results}

Heteroscedasticity test results with Glejser test shows that the independent and dependent variables are normal with values above 0.05 , it can be concluded that there is no heterokedasticity in the tested variables.

\section{Hypothesis testing Test Results F}

The $F$ test shows that all independent variables jointly influence the dependent variable. $F$ test is done by looking at the significance value. Probability values less than 0.05 then the regression model can be used to predict the dependent variable (Ghozali, 2001).

\section{Test Results t}

Based on the results of the test, each hypothesis can be explained as follows;

Test results from $\mathrm{H} 1$ with Sig. of 0.001 and a value of $\mathrm{B}$ of 0.161 indicates that the recruitment and selection that is correct in accordance with the procedures carried out by the company is positively related significantly to the performance of logistics company employees in Batam. Thus it can be concluded that a good recruitment and selection process in recruiting will determine good employee performance. The results of this study are in accordance with research from Jouda et al., (2016), Tanveer et al., (2011), Bida et al., (2017).

$\mathrm{H} 2$ test results with Sig. of 0.013 and a value of $\mathrm{B}$ of 0.174 indicates that the compensation variable is significantly positively related to employee performance in Batam. The compensation system applied to logistics company employees in Batam is a factor in improving employee performance. The results of this study are consistent with research from Hassan (2016), Bida (2017), Bowra et al., (2011), Jouda et al., (2016), Kaveri \& Prabakaran (2013), Shabbir (2014), Bida et al. ., (2017).

$\mathrm{H} 3$ test results with Sig. of 0.020 and a value of $B$ of 0.169 indicates that the training program conducted by the company is positively related to the performance of logistics company employees in Batam. Thus it can be concluded that a well planned training program will affect the performance of company employees. These findings are consistent with findings from research from Hassan (2016), Jouda et al., (2016), Kaveri \& Prabakaran (2013), Tanveer et al., (2011), Bida et al., (2017).

H4 test results with Sig. of 0,000 and a value of $\mathrm{B}$ of 0.271 indicates that employee performance appraisal is significantly positively related to employee performance. Thus it can be concluded that the implementation of a good performance evaluation program and planned will be able to improve the performance of logistics company employees in Batam. These results are consistent with research from Hassan (2016), Bida (2017), Bowra et al., (2011), Jouda et al., (2016), Tanveer et al., (2011), Bida et al., (2017) ). 
Determination Coefficient Test Results (R2)

The coefficient of determination (R2) test is used to determine the effect of the dependent variable with the independent variable. In this study it is known that the adjusted R2 number of 0.421 means that the ability of the independent variable to explain the employee's performance is $42.1 \%$ while the remaining $57.9 \%$ is explained by other variables not examined in this study, such as the work environment (Odunlami and Matthew, 2014).

\section{CONCLUSIONS, LIMITATIONS AND RECOMMENDATIONS}

\section{Conclusion}

1. This study concludes that in H1 testing there is an influence and relationship between recruitment and selection variables on employee performance. The results of this study indicate that the process of recruitment and selection is good and in accordance with procedures established by the company to get the right person for a position is very important and will help improve the performance of logistics company employees in Batam. These findings are consistent with research from Tanveer et al., (2011).

2. H2 hypothesis testing results with multiple regression conclusions obtained that the compensation variable significantly influence the level of employee performance. This finding shows that compensation is an important factor affecting the performance of logistics company employees in Batam. The results of this study are consistent with research from Hussain \& Rehman (2013), Asim (2013).
3. The results of hypothesis testing $\mathrm{H} 3$ can be concluded that there is a significant influence between the variables of job training on employee performance. This shows that the training program provided by the company will improve the performance of logistics company employees in Batam. These findings are consistent with findings from studies from Farooq and Khan (2011), Hussain and Rehman (2013) and Amin et al., (2012).

4. The results of hypothesis testing $\mathrm{H} 4$ with multiple regression can be concluded that the performance appraisal variable has a significant effect on employee performance. These findings indicate that a structured employee work assessment system will improve the performance of logistics company employees in Batam. This result is consistent with research from Tanveer et al., (2011) and Iqbal et al., (2013).

\section{Limitation}

In this study there are also limitations;

1. The number of respondents is still limited to employees who work in logistics companies in Batam alone, not yet covering cities or other regions in Indonesia, so the results of this study still have limitations in explaining the influence between variables as a whole.

2. The variables studied are still limited to four independent variables, there are still many other variables that also have influence but are not examined in this study.

3. There are still obstacles in the distribution of questionnaires to respondents who are employees of logistics companies in Batam, one of which is due to the lack of 
understanding from the management of the company about the purpose of this study.

\section{Recommendation}

1. Based on the research and discussion in previous chapters, a number of things can be recommended as follows;

2. 1. Future studies should examine the effect of human resource practices on employee performance in other industrial fields such as bank employees, oil and gas sector companies, hospitals and other fields both in Batam and outside Batam.

3. 2. For further research can add other variables as independent variables that can affect employee performance such as motivation (Iqbal et al., 2013) and work involvement (Tabiu \& Nura 2013) because in previous studies from other researchers it was found that these variables had a significant effect on employee performance.

4. 3. Provide an explanation to the management and employees of the logistics company regarding the purpose of research and data collection, so that further misunderstandings arise from the company and employees that will be the object of research..

\section{BIBLIOGRAPHY}

Al-Qudah, M. K., Osman, A., Halim, M. S., \& Shatanawi, H. A., (2014). The Effect Of Human Resources Management Practices On Employee Performance. International Journal of Academic Research in Business and Social Sciences, Vol. 4, No. 4.

Ameeq, A. \& Hanif, F (2013) Impact of Training on Employee's Development and Performance in
Hotel Industry of Lahore, Pakistan. Journal of Business Studies Quarterly 2013, Volume 4, Number 4

Amin, A., Saeed,R., Lodhi,R.W., Simra,M., Iqbal, A. \& Tehreem, R. (2012) The Impact of Employees Training On the Job Performance in Education Sector of Pakistan. Middle-East Journal of Scientific Research 17 (9): 1273-1278, 2013.

Asim, M (2013). Impact of Motivation on Employee Performance with Effect of Training: Specific to Education Sector of Pakistan. International Journal of Scientific and Research Publications, Volume 3, Issue 9, September 20131 ISSN 2250-3153

Bowra, Z., Sharif B., Saeed A., dan Niazi, M. (2011). Impact of Human Resource Practices on Employee Perceived Performance in Banking Sector of Pakistan. African Journal of Business Management, 6(1), 323-332.

Bida, M.J (2017) Management Support as a Moderator in the HR Practice Employee Performance. International Journal of Management Research \& ReviewVolume 7/Issue 1/Article No-3/13-27-2017

Bida, M.J., Majid, A.H dan Ismail, A.I (2017) Establishing HR PracticesEmployee Performance Relationship through Literature Survey. Journal of Advanced Research in Business and Management Studies 6, Issue 1 (2017) 39-49

Chukwuka, E.J \& Nwakoby, N.P (2018) Effect of Human Resource Management Practices on Employee Retention and Performance in Nigerian Insurance Industry. World Journal of Research and Review (WJRR) ISSN: 2455-3956, Volume-6, Issue-4, April 2018 
Farooq, M \& Khan, M.A. (2011) Impact of Training and Feedback on Employee Performance Far East Journal of Psychology and Business Vol. 5 No. 1 October 2011

Ghozali, I (2011). Aplikasi Analisis Multivariate dengan Program SPSS, Badan Penerbit Universitas Diponegoro, Semarang

Hair, J.F., Black, W.C., Babin, B.J., dan Anderson, R.E. (2010). Multivariate Data Analysis. Seventh Edition. Prentice Hall, Upper Saddle River, New Jersey.

Hameed, A; Ramzan, M; Zubair, H.K \& Ali, G (2012) Impact of Compensation on Employee Performance (Empirical Evidence from Banking Sector of Pakistan. International Journal of Business and Social Science Vol. 5.2

Hassan, S (2016) Impact of HRM Practices on Employee's Performance. International Journal of Academic Research in Accounting, Finance and Management Sciences Vol. 6, No.1, January 2016, pp. 15-22

Hussain, T. dan Rehman, S.S. (2013) Do Human Resource Management Practices Inspire Employees' Retention? Research Journal of Applied Sciences, Engineering and Technology 6(19): 3625-3633, 2013

Ibrar, M \& Khan, O. (2015) The Impact of Reward on Employee Performance. International Letters of Social and Humanistic Sciences Vol. 52 (2015) pp 95-103

Indriantoro, N dan Supomo, B (2012). Metedologi Penelitian Bisnis. Yogyakarta : Edisi Pertama, Penerbit BPFE.

Iqbal, N., Ahmad, N \& Javaid, K (2014) Impact of Training on Employee Performance in the Context of Telecommunication Sector. International Letters of Social and
Humanistic Sciences 6 (2014) 6073 ISSN 2300-2697

Jagero, N. Komba, H.V \& Mlingi, M.D (2012) Relationship between on the Job Training and Employee's Performance in Courier. Companies in Dar es Salaam, Tanzania. International Journal of Humanities and Social Science Vol. 2 No. 22

Jouda, A.A., Ahmad, U.N., dan Dahleez, K.A. (2016) The Impact of Human Resource Management Practices on Employees Performance: The Case of Islamic University of Gaza in Palestine. International Review of Management and Marketing, 2016, 6(4), 1080-1088

Kaveri, M dan Prabakaran, G. (2013). Impact of High Performance Human Resource Practices on Employees' Job Performance in Leather Goods Manufacturing Companies at Vellore District. Bonfring International Journal of Industrial Engineering and Management Science, Vol. 3, No. 1, March 2013

Njanja, W.L., Maina, R.N, Kibet, L.K., \& Njagi, K (2013) Effect of Reward on Employee Performance: A Case of Kenya Power and Lighting Company Ltd., Nakuru, Kenya. International Journal of Business and Management; Vol. 8, No. 21; 2013

Odunlami, I.B., \& Matthew, A.O (2014) Compensation Management and Employees Performance in the Manufacturing Sector, A Case Study of a Reputable Organization in the Food and Beverage Industry. International Journal of Managerial Studies and Research Vol. 2, Issue 9, October 2014

Oladejo, M.O \& Oluwaseun, Y (2014) An Assessment of the impact of Compensation Plan on workers Performance of selected Quoted Food and Beverages 
Manufacturing Companies in Nigeria. Journal of Business and Management Vol. 16/7

Rizwan, M (2014) A Comparative Analysis of the Factors Effecting the Employee Motivation and Employee Performance in Pakistan. International Journal of Human Resource Studies 21623058 2014, Vol. 4, No. 3

Saeed, R.; Lodhi, R.N.; Simra, M.; Iqbal, A \& Tehreem, R (2013) The Impact of Employees Training On the Job Performance in Education Sector of Pakistan. Middle-East Journal of Scientific Research 17 (9): 1273-1278, 2013

Shabbir, M.S (2014). The Impact of Human Resource Practice on Employee Perceived Performance in Pharmaceutical Sector of Pakistan. African Journal of Business Management, Vol. 8 (15) pp 626-632

Siddiqi, T \& Tangem, S (2018) Impact of Working Environment, Compensation and Motivation on the Performance of Employees in the Insurance Companies of Bangladesh. South East Asia Journal of Contemporary Business, Economics and Law, Vol. 15, Issue 5(April) 2018 ISSN 2289-1560

Tabouli, E.M; Habtoor, N.A \& Nashief, M.S. (2016) The Impact of Human Resources Management on Employee Performance: Organizational Commitment Mediator Variable. Asian Social Science; Vol. 12, No. 9; 2016

Tabiu, A dan Nura, A. A (2013). Assessing the Effects of Human Resources Management (HRM) Practices on Employee Job Performance. Journal of Business Studies Quarterly 2013, Volume 5, Number 2

Wekesa, J.N \& Nyaroo. S. (2013). Effect of Compensation on Performance of Public Secondary School Teachers in Eldoret Municipality Kenya. International Journal of Scientific and Research Publications, Volume 3, Issue 6, June 2013 